Innlegg på inntil 400 ord lastes opp i http://mc.manuscriptcentral.com/tidsskriftet.

Redaksjonen forbeholder seg retten til å foreta redaksjonelle endringer.

Forfattere av vitenskapelige artikler har automatisk tilsvarsrett (jf. Vancouver-gruppens regler).

\section{Anestesilegene - den som leter skal finne}

I Tidsskriftet nr. $7 / 2010$ spør Kristoffer Lassen «Hvor ble det av anestesilegene?». Han etterlyser at anestesileger bruker sin kompetanse og inntar en mer forpliktende rolle utenfor operasjonsstuen (1).

De første, fåtallige anestesilegene arbeidet kun på operasjonsstuen med generell anestesi. Dette ga dem generelle kunnskaper og ferdigheter innenfor praktisk håndtering av patofysiologiske prosesser og livsviktige funksjoner, som igjen førte til fagets kraftige vekst innenfor fire «søyler»: anestesi, intensivmedisin, akuttmedisin og smertebehandling (2). Med sin brede faglige kontaktflate har anestesiologen etter hvert fått en sentral og anerkjent rolle i samhandling med operasjonspasienter og alle typer akutte eller alvorlig syke pasienter.

Rollen rundt operasjonspasienter kan defineres snevert, fra kun å gi anestesi under operasjoner, til altomfattende: fra og med skriving av primærjournal til hovedsamtale ved utskrivning. Som Lassen anfører, vil den siste ytterligheten bli feil; pasienten kommer tross alt til sykehuset med symptomer og lidelse, og har primært behov for diagnostikk og behandling. Nettopp i våre dager, med mange adjuvante, oppstykkede og spesialiserte tilbud langs et pasientforløp, er det sterkt behov for én ansvarlig og koordinerende lege. Dette bør, naturlig nok, være kirurgen når den operative behandlingen er sentral i forløpet. Det er imidlertid behov for å nyansere bildet av tette skott, som Lassen beskriver. I Norge er det vanlig at anestesiologene har det daglige, overordnede og koordinerende ansvaret for alle svært syke pasienter på generelle og kirurgiske intensivavdelinger. Også i den omfattende og økende dagkirurgiske virksomheten er anestesilegen aktivt med $\mathrm{i}$ forberedelse av pasienten, ved siden av å delta under hele det perioperative forløp, klarere for hjemsendelse og følge opp smertelindring og funksjon etter utskrivning. Anestesilegen er med i forberedelser og tar hånd om alle operasjonspasienter på oppvåkningsavdelinger. Pasienter på sengepost derimot har tradisjonelt hatt liten plass i anestesiologens hverdag. Det er i denne sammenheng viktig å definere sengepostens rolle og ressurstilfang - i grenseoppgangen mot overvåkingsavdeling på den ene side og rent sykehotell på den annen. Man kan også tenke seg klarere differensiering av forskjellige typer sengeposter, ikke bare ut fra pleie- og overvåkingsbehov, men ut fra behovet for spesialisert teamtilnærming rundt optimal rehabilitering og restitusjon etter operasjoner. I dette arbeidet er det naturlig å involvere anestesiologen. I en slik prosess bør økt ansvar og involvering også følges av økt innflytelse og myndighet. Historisk sett har det ikke alltid vært forståelse for denne sammenhengen. Men etter hvert er kirurgenes felt blitt smalere, og de har blitt mer subspesialisert i forhold til andre legegrupper og medarbeidere. En målrettet involvering av anestesiologer på sengepost bør forankres $i$ en forutgående avgrensing av oppgavene, både for å sikre rasjonell utnyttelse av kompetanse der den behøves best, og for å unngå flere «kokker» og mer ansvarspulverisering enn nødvendig.

\section{Johan Ræder}

Oslo universitetssykehus

og

Universitetet i Oslo

\section{Per Meinich}

Universitetssykehuset i Akershus

\section{Kristin Sem Thagaard}

Oslo universitetssykehus

\section{Litteratur}

1. Lassen K. Hvor ble det av anestesilegene? Tidsskr Nor Legeforen 2010; 130: 720.

2. Ræder J, Sandberg M. Anestesiologi. Tidsskr Nor Lægeforen 2006; 126: 83-4.

\section{På tide å endre journalpraksis}

Det var med stor glede jeg leste innleggene til Anne Sofie Frøyshov Larsen og Dag Helle i nr. 6/ 2010 (1, 2). Tiden til kritisk å kvalitetssikre journalene er for lengst overmoden. Som leger er vi tilvent en tradisjon med betydelig tendens til overvurdering av egne evner til å prestere god sakprosa. Virkeligheten er dessverre at mange av oss skriver særdeles dårlig prosa - som nesten aldri blir kvalitetssikret.
Avkrysningsskjemaer både for anamnese og funn kan lages meget presise. Elektronikken kan hjelpe oss til å finstemme dette til gode hjelpemidler med rullegardinmenyer og tilhørende databaser. Journaler nedtegnet på denne måten gjør at all relevant informasjon gjenfinnes i systematiske databaser.

Det er åtte år siden jeg så dette i praksis på en studietur til Japan og Kameda-sykehuset, som allerede den gang var papirfritt og diktatfritt og der all informasjon ble ført av legene i rullegardinmenyer. Menyene var felles for alle spesialiteter i dette store og fulldifferensierte sykehuset. Å klikke seg frem til eget fagfelt og legge inn pasientens sykehistorie og funn var ukomplisert og ble behersket av alle legene etter en ukes innføringskurs.

I dag brukes store ressurser på å utvikle talegjenkjenningsverktøy der diktat omformes til tekst direkte i den digitale journalen. Tanken er å spare sekretærutgifter og få ferdigstilt tekst på plass uten venting på skrivehjelp. Etter min mening er dette et unødvendig sidespor, som ikke vil heve kvaliteten på det ferdige produktet.

Larsen argumenterer også for at pasienten skal eie sin journal. Selv om vi nå har fått et lovverk som åpner for journaltilgang på tvers av foretakene - foreløpig riktignok bare innen eget regionalt foretak - er dette ingen dårlig idé. Mange av de store internasjonale dataoperatørene arbeider intenst med slike løsninger. Jeg ser for meg at vi alle utstyres med et kort med databrikke, som vanligvis bare kan åpnes av en selv (personlig kode) eller av den kortinnehaver gir myndighet til, men hvor det også finnes en «blålysmulighet» for akutte situasjoner. Hvordan back-up ordnes ellers, er et rent teknisk spørsmål. Et slikt kort vil bli tatt vare på - det er sjelden at folk mister sine bankkort. Alle medisinske opplysninger føres fortløpende av sykehus, fastlege og eventuelt andre medisinske kontakter. Dette vil gi god og meningsfylt dokumentasjon om den enkeltes helse og medikasjon.

\section{Emil Mohr}

Helse Fonna

\footnotetext{
Litteratur

1. Larsen AS. Hvorfor leker vi fortsatt hviskeleken? Tidsskr Nor Legeforen 2010; 130: 594.

2. Helle D. Farlige sykehusjournaler. Tidsskr Nor Legeforen 2010; 130: 594.
} 